\section{APOLOGY}

Due to a printing error, the guest editor of REFUGE Vol. 7, No.1, October 1987 was incorrectly listed. The publisher and Refugee Documentation Project staff apologize to $\mathrm{Mr}$. Daniel C. Levy who was the Guest Editor of that edition. Barbara Harrell-Bond was Guest Editor of Volume 6 , No.4 only. We regret any embarrassment this may have caused either party.

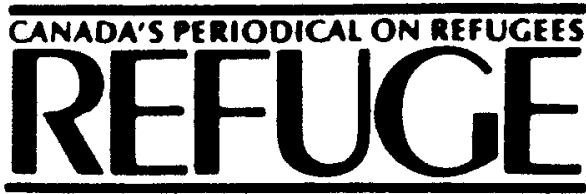

clo Refugee Oocumentation Project. York University 4700 Keele Street. North York. Ontario M3J 1P3

\section{Editor: \\ Michael Lanphier \\ Managing Editor:
Noreen Nimmons}

Assistant Managing Editor:
Joan Atlin

Editorial Assistance: Marilyn Walker

Refuge is dedicated to the encouragement of assistance to refugees by providing a forum for sharing information and opinion on $\mathrm{Ca}$ nadian and international issues pertaining to refugees. It is published four times a year by the Refugee Documentation Project. It is a non-profit. independent periodical supported by private donations and by subscriptions. It is a forum for discussion, and the views expressed do not necessarily reflect those of its funders or staff.

All materials in Refuge may be reproduced without permission unless copyrighted or otherwise indicated. Credit should be given to the author or source, if named.

Subscription rates for one year are $\$ 20.00$ in Canada and US $\$ 25.00$ overseas. Please enclose payment with your order.

Logo design:

Dreadnaught Co-operative Inc. Toronto.

Typesetting, layout and printing: Our Times Ltd., Toronto.

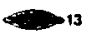

Second Class Mail Registration No. 5512 ISSN 0229-5113

\title{
EDITORIAL: A Call to Order
}

In this second edition on refugee protection in North America, non-governmental organizations (NGOs) call the modern $\mathrm{Ca}$ nadian state to order by pointing an accusatory finger at its presumptive legislative powers. The impending Parliamentary Bill C-55 on refugee determination and C84 on security measures presently await review of a skeptical and unusually assertive Senate. Senators, no less than the NGO representatives in this issue, are querying what powers legislation should accord to the state when individual rights are thereby infringed. It is a perennial question in academic political science and sociology debates. But this "chestnut" has fallen against the hard surface of restrictive practices such as categoric exclusion of refugees without individual examination, and peremptory arrest and detention upon suspicion.

Resultantly, Canadian NGOs have moved one step closer to confronting the very government upon which they depend for their own protection or funding, or both. Not a pleasant spontaneous reaction. After internal deliberation, NGOs have opted for confrontation instead of cooperation, upon accusation instead of acquiescence. This is a risky course. Canada's highly respected record of government-NGO collaboration knows few international peers. Yet mutual respect has given way to suspicion and discreditation.
Clearly, NGOs perceive that the state is legislating administrative convenience under the guise of efficiency. The articles in this edition detail cutting the comerstone of refugee protection. Presumably, if restrictions on accessibility are not introduced, Canada's shores and borders will be flooded with claimants whose motives combine to "clog the system" while taking advantage of Canada's social welfare.

And so it is up to NGOs to remind the government that refugee concerns are above all concerns of the individual who by definition is fleeing because of persecution, past or future. A government such as Canada can neither afford the luxury of cornercutting when individual lives may be imperiled nor arrogate to itself an otiose power to commandeer undesirable suspects upon discretion of categoric presumption.

The modern state is the most powerful instrument yet created by mankind. It behooves Canada in its very modernity to recall the raison d'etre for legislation: to protect the individual. At state's greatness can be measured, not by its restrictiveness, but by compassion for its weakest individuals, thus bringing order into the disorderly world of the dispossessed in flight.

\section{Michael Lanphier, Editor}

\section{Government of Canada refugee plan \\ 1988 allocations by world area, compared with 1987 allocations}

Eastern Europe
Southeast Asia
Latin America
Africa
Middle East \& West Asia
Other World areas
Funded management reserve

TOTAL:

\begin{tabular}{rr}
1987 & 1988 \\
\hline 3,100 & 3,400 \\
3,200 & 3,000 \\
3,200 & 3,400 \\
1,000 & 1,000 \\
900 & 1,800 \\
300 & 100 \\
300 & 300 \\
\hline 12,000 & $13,000^{*}$
\end{tabular}

* In addition to these government-assisted refugees, the government will also admit without limitation, refugees sponsored by Canadian volunteer groups (private sponsors). It is estimated that there will be about 6,000 such private sponsorships in 1988, an increase of 1,000 over 1987.

Government of Canada. Annual Report to Parliament on Future Immigration Levels, Ottawa, December 1987. 